\title{
Аналіз теоретичних досліджень інтенсифікованого теплообміну в трубах
}

\author{
В.І.Мельник ${ }^{1}$, Б.М.Цимбал ${ }^{2}$ \\ ${ }^{1}$ Харківській національний технічний університет сільського господарства \\ імені Петра Василенка (м. Харків, Україна) \\ ${ }^{2}$ Національний університет цивільного захисту України (м. Харків, Україна) \\ email: ${ }^{1}$ victor_melnik@ukr.net, ${ }^{2}$ tsembalbogdan@ukr.net ORCID: ${ }^{2}$ 0000-0002-2317-3428
}

В роботі на основі аналізу математичних моделей обґрунтовано недоліки і переваги різних конструкцій теплообмінників з завихрювачами та їх вплив на гідродинаміку і теплообмін закручених потоків. Більшість теплообмінників з завихрювачами мають складну форму. Збільшення теплообміну при застосуванні гвинтових закручувачів потоку відбувається завдяки інтенсифрікації теплообміну між ядром потоку та приграничним шаром. Відбувається це при турбулізації закрученого потоку під впливом відцентрових сил. В такому разі ефективна швидкість вища ніж при звичайній турбулентності потоку. Процес протікає більш інтенсивно при низьких числах Рейнольдса.

При ламінарних режимах течії визначальним механізмом перенесення тепла $є$ теплопровідність поперек потоку, по нормалі до стінки. В такому випадку інтенсивність тепловіддачі відносно мала. Для підвищення теплопередачі треба використовувати труби з гвинтовою поверхнею теплообміну (однозахідною та багатозахідною спіральною накаткою), в яких відбувається ламінарний закручений рух рідини. На відміну від турбулентної течії, в ламінарному потоці термічний опір в каналі більш рівномірно розподілений по всьому його поперечному перетині, тому для інтенсифікації тепловіддачі необхідний вплив, що збурює потік в межах зони пристінної течії.

Найбільш перспективними є теплообмінники з труб з однозахідною або багатозахідною спіральною накаткою. На відміну від трубчастих теплообмінників без накатки, вони мають більшу площу теплообміну та меншу матеріалоємність. При цьому на відміну від стрічкових вставок та закручувачів, труби з накаткою мають гідравлічний опір пристінного шару, який зменшується швидше, ніж зростають втрати тиску.

Використання труб з спіральною накаткою в енергетичних палях з теплообмінниками дозволить знизити масо-габаритні характеристики не тільки теплообмінника, але й самої палі. В такому випадку інтенсифікація теплообміну визначається гідродинамікою потоку у в'язкому пристінному шарі, тобто порушенням упорядкованості течії рідини за рахунок його закручування.

Проведений аналіз відомих математичних моделей інтенсифікаторів теплообміну дозволяє сформувати вимоги до перспективних конструкцій теплообмінників. В подальшому це дасть можливість розробити нову математичну модель гідродинаміки та теплообміну у забивній палі з Uподібним теплообмінником в якій враховані всі приведені в роботі недоліки. Спираючись на дослідження гідродинаміки і теплообмінних процесів потрібно провести оптимізацію конструкції теплообмінника, а саме, геометрію поперечного перетину труб, форму укладки труб в тілі палі, а також глибину, кут і ширину поглиблень спіральної накатки.

Ключові слова: паля, теплообмінник, накатка, теплота, ефективність, гідравлічні втрати, число Нусельта, математична модель, оптимізація.

Постановка проблеми. Переважна більшість теплообмінників в палях мають круглу фрорму, низьку теплопередачу та велику матеріалоємність. Підвищення швидкості теплоносія, а також застосування внутрішнього оребрення $є$ найбільш розповсюдженим способом підвищення інтенсивності конвекційного теплообміну. Такий підхід не завжди є раціональним, тому що призводить до збільшення гідродинамічного опору, що, в свою чергу, збільшує необхідну потужність на прокачування теплоносія.
Метою роботи $є$ виявлення невирішених раніше гідродинамічних та теплообмінних проблем i недоліків інтенсифікованого теплообміну в трубах теплообмінників інтегрованих в конструкцію паль для подальшого їх вдосконалення і адаптації під специфічні вимоги будівель та споруд молочних фермерських господарств великої рогатої худоби.

Задачею дослідження $\epsilon$ аналіз відомих математичних моделей, параметрів, ефективності, недоліків і переваг інтенсифрікаторів теплообміну в трубах теплообмінників інтегрованих в конструкцію паль. 
Головна частина. Закручування потоку за допомогою гвинтових вставок. В роботі [1] представлені теоретичні та експериментальні дослідження інтенсифрікованого теплообміну при турбулентній течії в трубах з застосуванням стрічкових закручувачів потоку. Розрахункові, теоретичні данні, які були отриманні в роботі [1] по коефріцієнту тертя у трубі зі скрученою стрічкою при класичних граничних умовах, як для повітря, так і для води, в порівнянні з експериментальними, мають задовільну кореляцію в широкому діапазоні чисел Рейнольдса, Прандля та геометрії скрученої стрічки (ії̈ відносних кроків). До недоліків цієї теорії можливо віднести те, що при отриманні остаточного виразу (1) були введені додаткові емпіричні сталі. Залежність для коефіцієнту гідравлічного опору для труби зі скрученою стрічкою наступна:

$$
\begin{aligned}
& \xi=\xi_{0} \mid \frac{1}{\pi+2}\left(\pi \sqrt{1+4\left(\frac{\pi R_{0}}{H}\right)^{2}}+\frac{2 \pi R_{0}}{H} \times\right. \\
& \left(\sqrt{1+\left(\frac{H}{\pi R_{0}}\right)^{2}}+\left(\frac{H}{\pi R_{0}}\right)^{2} \ln \left(\frac{2 \pi R_{0}}{H}+\right.\right. \\
& \left.+\sqrt{\left.1+4\left(\frac{\pi R_{0}}{H}\right)^{2}\right)}\right)||^{\frac{3 n+1}{n+1}} \times \\
& \times\left[-\left\{\frac{2 \pi R_{0}}{H}\left(\pi-\frac{t}{R_{0}}\right)+\right.\right. \\
& +\frac{\pi R_{0}}{H} \sqrt{1+4\left(\frac{\pi R_{0}}{H}\right)^{2}} \times \\
& \times\left(1+\frac{1}{8}\left(\frac{H}{\pi R_{0}}\right)^{2}\right)-\frac{1}{32}\left(\frac{H}{\pi R_{0}}\right)^{2} \times \\
& \left.\ln \frac{\sqrt{1+4\left(\frac{\pi R_{0}}{H}\right)^{2}}+\frac{2 \pi R_{0}}{H}}{\sqrt{1+4\left(\frac{\pi R_{0}}{H}\right)^{2}}-\frac{2 \pi R_{0}}{H}}\right\}^{\frac{3}{2}} \times \\
& \times\left\langle\frac{1}{\pi+2} \times\left(\pi \sqrt{1+4\left(\frac{\pi R_{0}}{H}\right)^{2}}+\right.\right. \\
& \frac{2 \pi R_{0}}{H}\left(\sqrt{1+\left(\frac{H}{\pi R_{0}}\right)^{2}}++\left(\frac{H}{\pi R_{0}}\right)^{2} \times\right. \\
& \left.\times \ln \left(\frac{2 \pi R_{0}}{H}+\sqrt{1+4\left(\frac{\pi R_{0}}{H}\right)^{2}}\right)\right)\left.\right|^{\frac{3 n+1}{n+1}} \times
\end{aligned}
$$

$$
\begin{gathered}
\times\left\{\frac { 1 } { \pi + 2 - \frac { t } { R _ { 0 } } } \left(\left(\pi-\frac{t}{R_{0}}\right)+\left(1+\frac{2 \pi R_{0}}{H}\right)+\right.\right. \\
+\sqrt{1+4\left(\frac{\pi R_{0}}{H}\right)^{2}}\left(1-\frac{2 \pi R_{0}}{H}-\frac{H}{8 \pi R_{0}}\right)+ \\
\left.\left.\frac{H}{4 \pi R_{0}}\left(1+\frac{H}{8 \pi R_{0}}\right) \ln \left[\frac{\left(\sqrt{1+4\left(\frac{\pi R_{0}}{H}\right)^{2}}+\frac{2 \pi R_{0}}{H}\right)}{\left(\sqrt{1+4\left(\frac{\pi R_{0}}{H}\right)^{2}}-\frac{2 \pi R_{0}}{H}\right)}\right]\right)\right\}^{-2} \\
\Lambda_{2} \operatorname{Re}^{\left.-\frac{2}{1-n}+1\right],}
\end{gathered}
$$

де $\Lambda_{2}$ - емпірична константа; $\mathrm{n}$ - постійна «степеневого» закону; $\xi_{0}-$ коесріцієнт тертя в трубі зі скрученою стрічкою та труби без стрічки; $H$ та $t-$ крок та товщина скрученої стрічки; $R_{0}$ - радіус круглої труби; $R e$ - число Рейнольдса.

Збільшення теплообміну при застосуванні гвинтових закручувачів потоку відбувається завдяки інтенсифрікації теплообміну між ядром потоку та приграничним шаром. Це відбувається під впливом відцентрових сил при турбулізації закрученого потоку, причому інтенсивніше при більш низьких числах Рейнольдса, ніж при звичайній турбулентності потоку, оскільки ефективна швидкість в такому випадку вища. Дана теорія має певні переваги при розрахунку усередненого теплообміну при турбулентній течії теплоносія в трубах з стрічковими закручувачами потоку при односторонньому теплообміні, але вона має недолік більш високу складність.

При закручувані потоку місцеві пристінкові швидкості збільшуються та змінюється характер загальної течії. Закручування потоку в трубах здійснюється шляхом використання закручених стрічок та шнеків (рис. 1). При цьому такий характер руху підтримується безперервно по всій довжині труби, що забезпечує сталість співвідношення тангенціальної та осьової складової швидкості.

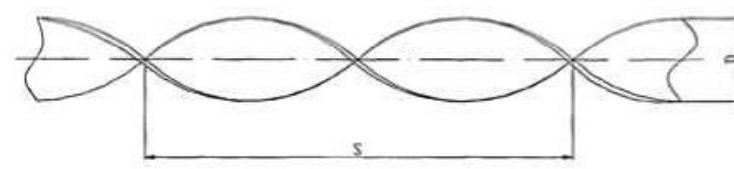

a

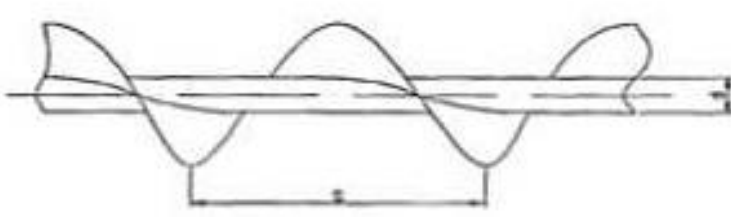

6

Рис. 1. Гвинтові вставки:

а - закручена стрічка; б - шнек 
При закручуванні потоку стрічкою в поперечному перерізі рідина перетікає від периферії до центру в результаті дії градієнту тиску. Крім того, рідина з приграничного шару проникає в ядро потоку. Ці рухи призводять до виникнення чотирьох вихрових областей (рис. 2), які сприяють посиленню теплообміну і спільно з дією відцентрових сил зменшують товщину приграничного шару. Вихрове змішування також сприяє виникненню турбулентного течії при менших числах $R_{e}$.

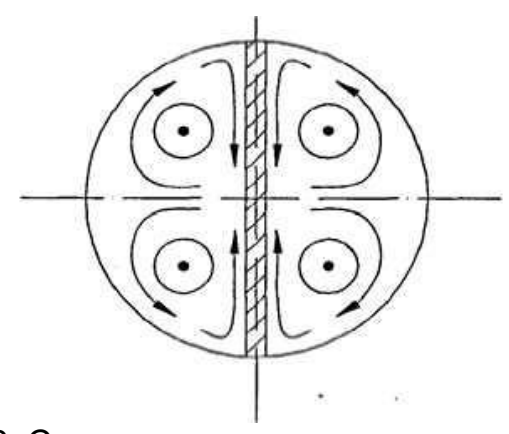

Рис. 2. Схема утворення вторинних течій в трубі з закрученою стрічкою

При ламінарних режимах течії визначальним механізмом перенесення тепла $€$ теплопровідність (поперек потоку, по нормалі до стінки), тому інтенсивність тепловіддачі відносно мала. На відміну від турбулентної течії, в ламінарному (перехідному) потоці термічний опір в каналі більш рівномірно розподілений по всьому його поперечному перерізі, тому для інтенсифрікації тепловіддачі необхідний вплив, що збурює на велику зону пристінної течії. Стрічкові завихрювачі для створення таких реимів особливо ефективні. Аналіз, проведений в різних роботах, показує, що збільшення тепловіддачі, яке отримано за допомогою закручувачів, в перехідному і турбулентному режимах 3 ростом числа Рейнольдса значно падає, і тому використовувати закручувачі при великих числах Рейнольдса для потоку в трубі не рекомендується.

Використання періодично кільцевих виступів. Кільцева діафррагма та канавки турбулізують потік в пристінному шарі і забезпечують інтенсифікацію теплообміну зовні та всередині труб (рис. 3). В роботі [2] для труб з кільцевими турбулізаторами отримані залежності для визначення коефіцієнтів тепловіддачі та гідравлічного опору від числа Рейнольдса $R e$, кроку розташування турбулізаторів $t / D$ та висоти турбулізатора $d / D$. У всіх залежностях збільшення поверхні теплообміну в трубах з кільцевими турбулізаторами та в пучках труб не враховувалось збільшення поверхні теплообміну. При розрахунках коефіцієнтів тепловіддачі, щільність потоку визначалась по поверхні гладкої труби, що є певним недоліком. Поздовжній переріз труби з кільцевою накаткою показано на рис. 3.

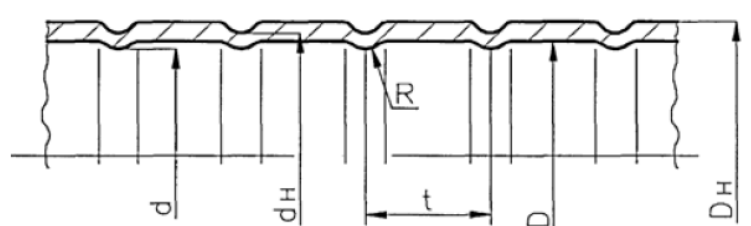

Рис.3. Поздовжній переріз труби з кільцевою накаткою

Середня тепловіддача для крапельних рідин при $t / D=0,5$ та $d / D \geq 0,94$, згідно роботи [2] складає:

$$
N u / N u_{\text {гл }}=[100(1+d / D)]^{0.445},
$$

де $N u$ - число Нусільта, яке при нагріванні газів визначають за формулою:

$$
N u_{\text {гл }}=0,0216 \operatorname{Re}^{0,8} \operatorname{Pr}^{0.445},
$$

де $\mathrm{Pr}$ - число Прандля.

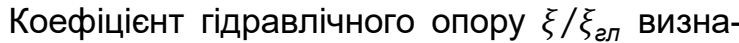
чено в роботі [2] як відношення швидкості потоку

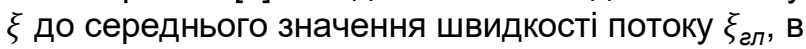
діапазоні $\operatorname{Re}=10^{4}-4 \cdot 10^{5}$ наступною залежністю:

для $d / D=0,9 \ldots 0,97$ та $t / D=0,5 \ldots 10,0$

$$
\begin{aligned}
\frac{\xi}{\xi_{\text {гл }}}=[ & \left.\frac{100(\lg \operatorname{Re}-4,6)(1-d / D)^{1,65}}{\exp (t / D)^{0,3}}\right] \times \\
& \times \exp \left[\frac{25(1-d / D)^{1,32}}{(t / D)^{0,75}}\right],
\end{aligned}
$$

де

$$
\xi_{\text {гл }}=\frac{0,316}{\operatorname{Re}^{0,254}}\left(\frac{\mu_{n}}{\mu_{c}}\right)^{n},
$$

де $\mu_{n}$ та $\mu_{c}$ - молекулярна та динамічна в'язкість; $n=0,14$ для нагріву газів; $n=0$ для охолодження газів; $n=1 / 3$ для нагріву рідин.

Канали зі спіральними виступами і пружинними вставками. У трубах зі спіральними виступами інтенсифікація обумовлена спільною дією двох фракторів: турбулізацією і руйнуванням пристінкового шару течії виступами і закручуванням пристінкового потоку під дією виступів. Інтенсифікуючий вплив часткового закручування течії низьким виступом (тільки пристінної зони) реалізується через збільшення пристінної швидкості потоку. Цей спосіб слід віднести до комбінованого способу інтенсифрікації теплообміну, так як на потік одночасно діє турбулізація і закрутка.

Інтенсифікатори типу «дифузор-конфузор». Трубчасті поверхні теплообміну з хвилястими стінками складаються з ділянок конфузорів і дифузорів, які виготовляються шляхом накатки спеціальними роликами (рис. 4). Кути розширення дифузорів і конфузорів вибираються за умовою отримання потоку з нестаціонарними відривними явищами. Такі відриви потоку інтенсифікують теплообмін. 


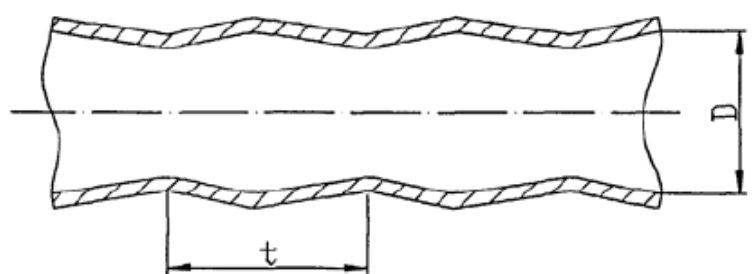

Рис. 4. Поздовжній перетин труби типу конфузом-дифффузор

При малій відносній довжині дифузору і при наявності підпору за рахунок конфузору відриви потоку носять нестаціонарний характер, що сприятливо позначається на інтенсифрікації теплообміну. Зовнішня турбулентність при негативному градієнті тиску сприяє інтенсифрікації теплообміну. Зазначені умови реалізуються в даному випадку наступним чином: турбулентність генерується в дифффузорній області і сприятливо впливає в конфузорній області.

Дані труби характеризуються відносно низьким опором і високим теплообміном. Знімання тепла при рівному опорі збільшується приблизно в 1,5 рази.

Труби типу «конфузор-дифффузор» перспективні для застосування і в ламінарному, і в перехідному режимах течії різних середовищ в трубах теплообмінників. Експерименти в роботах [2] показують, що при однакових 3 гладкою трубою енерговитратах на прокачування масла в таких трубах при перехідному режимі теплознімання збільшується на 40 - 70\%.

Подвійні турбулізатори. В роботі [3] моделювання граничного ізотермічного теплообміну за умови турбулентної течії в плоских каналах за рахунок турбулізації потоку виконували за аналогічною методикою, яку було застосовано для круглих труб в роботах [4-9] і кільцевих каналів з турбулізаторами в роботах [10-14]. Під час моделювання було отримано нелінійне рівняння для граничного коефріцієнта гідравлічного опору $\bar{w}_{x}$ плоского каналу з подвійними турбулізаторами:

$$
\begin{aligned}
& \bar{w}_{x}=\int_{0}^{1} w_{x} d Y=\mid \int_{1-\frac{4 A \sqrt{2}}{\sqrt{\varepsilon} R e}}^{1} \bar{w}_{x} \frac{\operatorname{Re} \varepsilon}{16} Y d Y+\int_{0}^{1-\frac{4 A \sqrt{2}}{\sqrt{\varepsilon} \mathrm{Re}}} \bar{w}_{x} \times \\
& \times\left\{\frac{\sqrt{\xi}}{2 \sqrt{2}} B+\frac{\xi}{32 \sigma}\left[\left(1-\frac{4 A \sqrt{2}}{R e \sqrt{\xi}}\right)^{2}-\frac{(1-Y)^{2}}{2}\right]\right\} d y \mid
\end{aligned}
$$

де $A, B, k, \sigma-$ константи, які детермінізуються: А - характеризує середню межу струменевої області; В - характеризує коефріцієнт пропорційності між поздовжньою швидкістю і швидкістю тертя (константи $\mathrm{A}=15 \div 114$ і В $=6,5 \div 8,5$ при зміні
$\left.R e=10^{4} \div 10^{5}\right) ; k=0,443-$ константа для універсального профрілю швидкості в турбулізованому потоці; $\sigma=0,013$ - константа для струменевого ядра потоку, що характеризує початкову турбулентність; $R e-$ число Рейнольдса по еквівалентному діаметру каналу; $\xi$ - коефіцієнт опору плоского каналу з турбулізаторами.

Схема інтенсифрікації теплообміну для плоского каналу за допомогою установки подвійних турбулізаторів представлено на рис. 5.

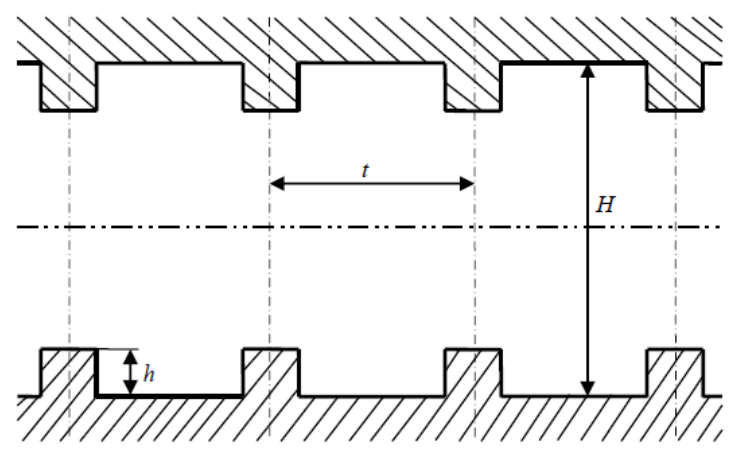

Рис. 5. Плоский канал з симетрично розташованими турбулізаторами однакових висот і кроків на обох поверхнях (подвійні турбулізатори)

Аналітичні залежності для кожного відповідного підшару мають вигляд:

$$
\begin{gathered}
I_{1}=\frac{2 \sqrt{2}}{\operatorname{Re} \sqrt{\xi}}\left\{\frac{2304}{\operatorname{Re}^{2} \xi}\left(\frac{q_{c 1}}{q_{c 2}}+1\right)-\right. \\
\left.-\frac{72 \sqrt{2}}{\operatorname{Re} \sqrt{\xi}} \frac{q_{c 2}}{q_{c 1}}-\frac{144 \sqrt{2}}{\operatorname{Re} \sqrt{\xi}}+6\right\},
\end{gathered}
$$

де $q_{c 1}$ та $q_{c 2}$ тепловий потік при зовнішньому та внутрішньому обігріві;

$$
\begin{aligned}
& I_{2}=\frac{2 \operatorname{Pr}_{T} B}{3 \operatorname{Re} \xi\left(\operatorname{Pr}_{T} B+\operatorname{Pr}_{T} A\right)} \times \\
& \times\left[\frac{32 \sqrt{2} A^{3}}{\sqrt{\xi}}\left(\frac{q_{c 2}}{q_{c 1}}\right)-24 A^{2} \operatorname{Re}-\right. \\
& -A^{2} \operatorname{Re} \frac{q_{c 2}}{q_{c 1}}+3 \sqrt{2} A \operatorname{Re}^{2} \sqrt{\xi}- \\
& -18 \sqrt{2} \operatorname{Re}^{2} \sqrt{\xi}+432 \operatorname{Re} \frac{q_{c 2}}{q_{c 1}}- \\
& \left.-\frac{6912 \sqrt{2}}{\sqrt{\xi}} \frac{q_{c 2}}{q_{c 1}}-\frac{6912 \sqrt{2}}{\sqrt{\xi}}\right]
\end{aligned}
$$

де $\mathrm{Pr}$ - число Прандтля;

$\mathrm{Pr}_{T}$ - турбулентне число Прандтля;

$$
I_{3}=\frac{\operatorname{Pr}\left(\frac{q_{c 2}}{q_{c 1}}\right)\left(\xi \operatorname{Re}^{2}-32 A^{2}\right)}{4 \xi \operatorname{Re}^{2}\left(\operatorname{Pr}_{T}+\sigma \operatorname{RePr}\right)}-\frac{\operatorname{Pr}\left(\frac{q_{c 2}}{q_{c 1}}+1\right)}{6\left(\operatorname{Pr}_{T}+\sigma \operatorname{RePr}\right)} \times
$$




$$
\times\left(\left(\sqrt{\frac{32}{\xi}} \frac{A}{R e}\right)^{3}-3\left(\sqrt{\frac{32}{\xi}} \frac{A}{R e}\right)-1\right)
$$

Для плоских каналів як з односторонніми, так і з двосторонніми турбулізаторами граничне перенесення теплоти не може переважати над перенесенням імпульсу, в той час як для круглих труб в певному інтервалі чисел Рейнольдса це можливо.

Інтенсифікатори завиток та діафрагма. 3 метою візуалізації процесів стратифікації в вихровій трубі авторами була розроблена твердотільна модель вихрової труби (рис. 6) і здійснено пряме чисельне моделювання процесів течії і теплообміну [15]. Авторами було виконано пряме чисельне моделювання, в пакеті прикладних програм обчислювальної гідродинаміки Flow Simulation 2012 виробництва компанії SolidWorks. Система рівнянь математичної моделі, яке вирішували апаратом програмного комплексу Flow Simulation, після розстановки граничних і початкових умов включає в себе: рівняння нерозривності, руху, енергії, турбулентної кінетичної енергії, дисипації турбулентної кінетичної енергії, стану Ван-дер-Ваальса і Редлиха-Квонга та рівняння дотичних напруженнь. Для опису термогазодинамічних характеристик турбулентних течій в квазістаціонарних постановці рівняння математичної моделі з класичної форми перетворюють методом Рейнольдса і записують в тензорному вигляді. Систему рівнянь руху середовища при чисельних розрахунках турбулентних течій автори доповнили моделями турбулентності, що дозволяють розрахувати значення турбулентних добавок, що входять в ці рівняння [16].

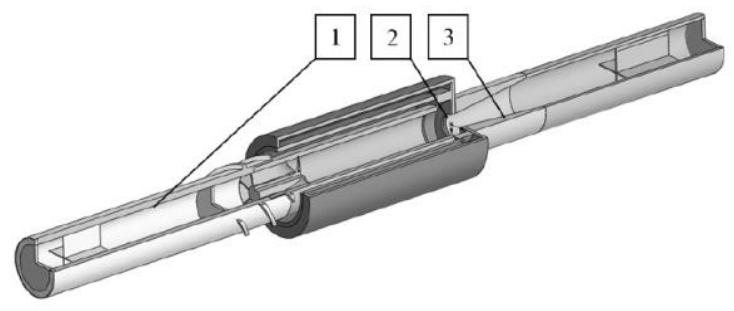

Рис. 6. Тривимірна твердотільна модель вихрової труби: 1 - камера енергетичного поділу; 2 - закручувальний пристрій (равлик); 3 - діафрагма

Візуалізація результатів чисельного моделювання течії газу в вихровій трубі за допомогою ліній струму, спроектованих на площину симетрії камери енергетичного поділу (рис. 7а), показує наявність замкнутих циркуляційних зон між центральним і периферійним потоками. Поле повних швидкостей потоку, представлене на рис. 7б, демонструє неоднорідність характеру течії газу i наявність зон загальмованого потоку в центральній частині вихрової труби (приблизно $90 \mathrm{~m} / \mathrm{c}$ ). Аналіз отриманих структур потоку дозволив їх розділити на структуру центрального потоку (приосьову) і великомасштабну вихрову структуру потоку (ВВС) (рис. 7в), що підтверджується результатами візуалізації течій в вихрових трубах.

Дослідження авторів характеру руху отриманих структур дозволило виявити такі особливості: BВC має закрутку відносно власної осі, що знаходиться в «центрі» структури, вісь ВВС не має закрутки, має фрорму спіралі і рухається уздовж осі вихрової труби в напрямку від тангенціального закручуючого пристрою в бік камери енергетичного поділу; осьовий потік має закрутку відносно власної осі і рухається уздовж неї в бік, протилежний руху ВВС, вісь має фрорму спіралі (рис. 7г).

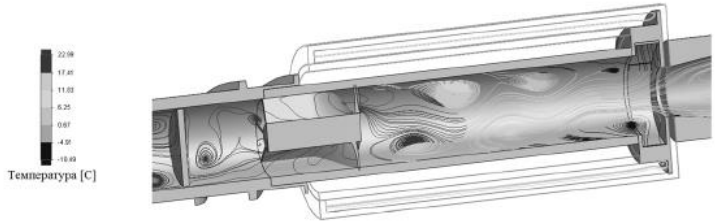

a

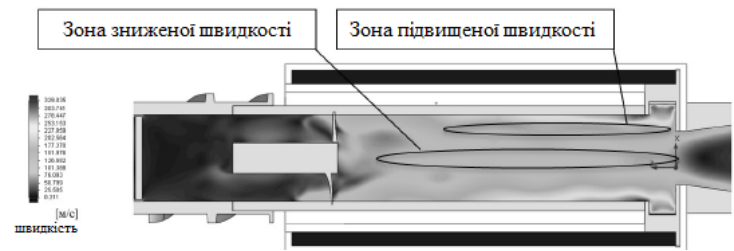

6

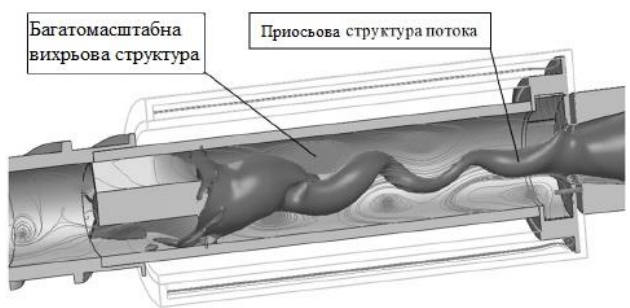

B

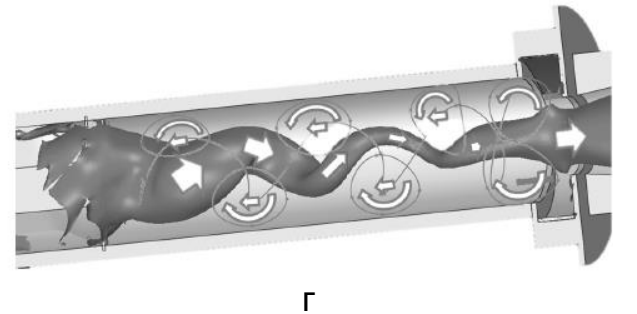

Рис. 7. Результати чисельного моделювання течії газу в вихровій трубі:

а - проекція ліній струму на площину симетрії камери енергетичного поділу; б - поле повних швидкостей потоку; в - просторова конфігурація центральної структури потоку (приосьової) і великомасштабної вихрової структури потоку

(BBC); г - схема закрутки потоків в структурі рухомого потоку в вихровій трубі 
Використання труб з гвинтовою поверхнею теплообміну. Авторами було проведено комп'ютерне моделювання теплогідродинамічних процесів та візуалізація структури потоків у жорсткій частині труб з гвинтовою поверхнею теплообміну з використанням програмного комплексу SolidWorks Flow Simulation. В якості об'єктів досліджень були прийняті труби з різним співвідношенням довжин фрагментів $\left(l_{1}: l_{2}\right)$, які формують теплообмінний елемент (рис. 8). Для всього діапазону чисел Re розрахунок чисел $\mathrm{Nu}$ та $\mathrm{Nu}$ проводили 3 використанням k-е моделі турбулентності.

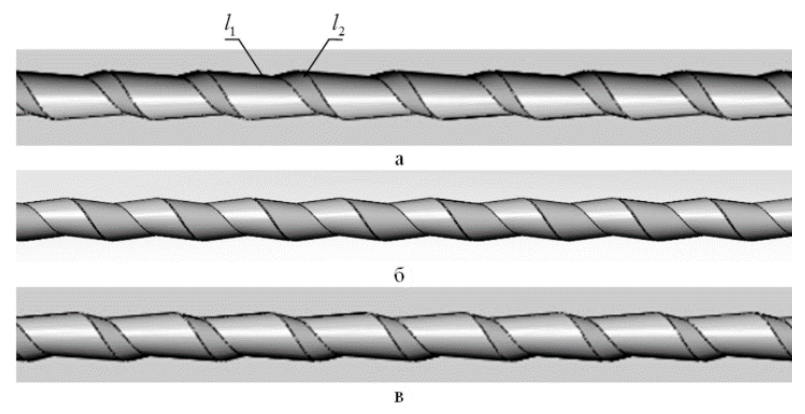

Рис. 8. Труби з співвідношенням довжин фрагментів $l_{1}: l_{2}$ : a $-1: 2 ;$ б $-1: 1 ;$ в $-2: 1$

На рис. 9 представлено основні етапи комп'ютерного моделювання процесів течії рідини та теплообміну з використанням середовища SolidWorks Flow Simulation.

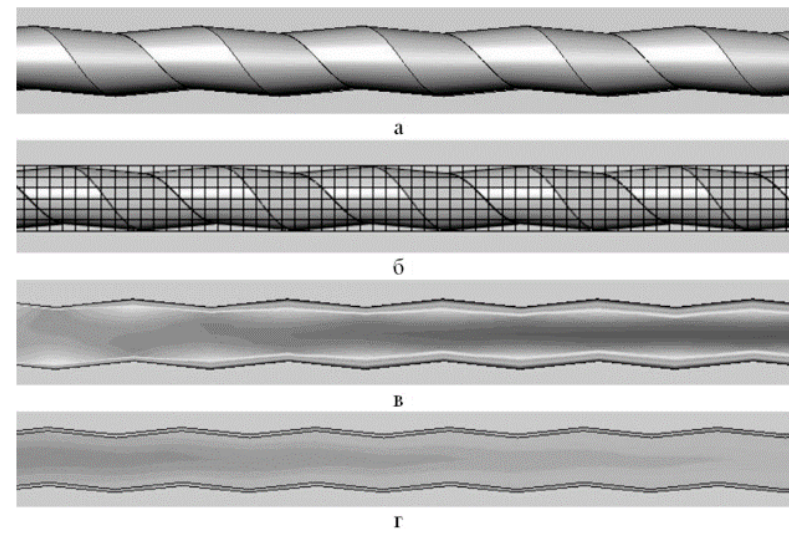

Рис. 9. Основні етапи моделювання в SolidWorks Flow Simulation:

a - створення 3D-моделі; б - побудова сітки розрахункової області; в - розподіл поля швидкостей; г - розподіл полю температур

Візуалізацію потоку рідин виконували по трьом параметрам: розподіл поля швидкостей, температур та тисків на початковій ділянці, в середній частині каналу та в вихідному перетині (рис. 10-12).

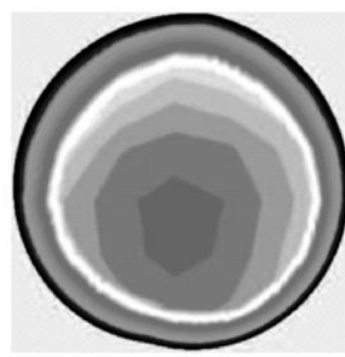

a

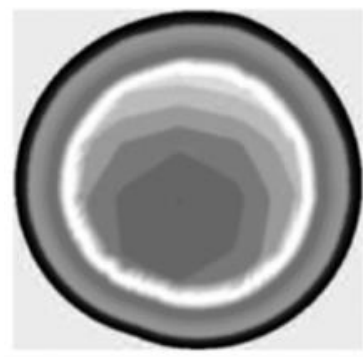

6

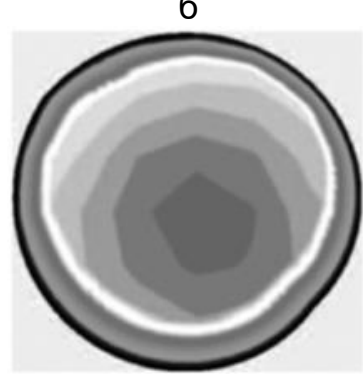

B

Рис. 10. Поле швидкостей $(\mathrm{Re}=35000)$ : a - початкова ділянка; б - середня частина каналу; в - вихідний перетин
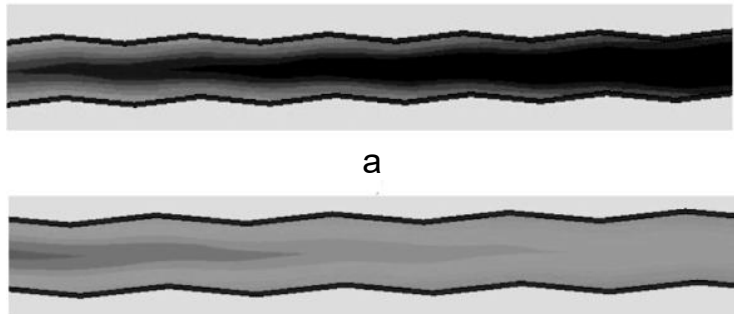

б

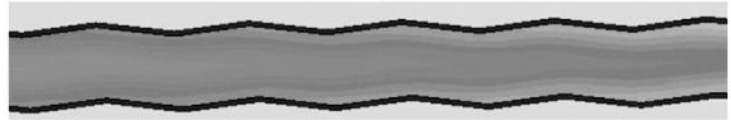

Рис. 11. Розподіл поля температур по довжині каналу: а - початкова ділянка; б - середня частина каналу; в - вихідний перетин

Авторами було визначено характер розподілу поля швидкостей, температур та тисків у розрахунковій області, приведено порівняльний аналіз теплогідродинамічної ефективності досліджуваних труб та оцінено значення коефіцієнтів 
тепловіддачі в міцній частині каналів і показано перспективність використання труб з гвинтовою поверхнею теплообміну при проектуванні сучасних енергоефективних теплообмінних апаратів гравітаційного і центробіжних типів [17].

Використання трубки зі спіральною гофрою. Застосування теплообмінника зі спіральною гофрою на внутрішній стінці є пасивним додатковим методом підсилення теплопередачі для гладкої спіральної трубки. Авторами роботи [18] було проведено чисельне моделювання для отримання турбулентного потоку та полів температури в гвинтовій трубці, які взаємодіють зі спіральною гофрою. Було досліджено вплив параметрів спірального гофрування і числа Рейнольдса на досліджуваний потік і теплообмін.

Фізична модель трубки зі спіральною гофрою, показана на рис. 12. Спіральне гофрування розташоване на внутрішній стінці гвинтової трубки, яка також має спіральне ребро на зовнішній стінці трубки. На рис. $12, R_{c}$ - радіус кривизни гладкої спіральної трубки, $H-$ крок спіральної трубки і а - радіус трубки. Ф - кут, що обертається вздовж гвинтової лінії гладкої спіральної трубки. Форма перерізу спірального гофрування напівкругла та e - глибина спірального гофрування. 3 метою вивчення впливу спірального гофрування на подальше посилення теплопередачі гвинтової трубки крок спірального гофрування $h$ визначається так:

$$
h=\frac{N_{1} \sqrt{\left(2 \pi R_{c}\right)^{2}+H^{2}}}{N_{2}},
$$

де $N_{1}$ - кількість витків гладкої спіральної трубки, а $N_{2}$ - кількість витків спіралі гофрування навколо гвинтової трубки. У цій статті вибрано два витки гладкої спіральної трубки, тобто $N_{1}=2$ або обчислювальна область в осьовому напрямку простягається від $\Phi=0^{\circ}$ до $\Phi=720^{\circ}$. Вивчається крок гофрування $h$ та глибина гофру $e=1$ мм спіралі.

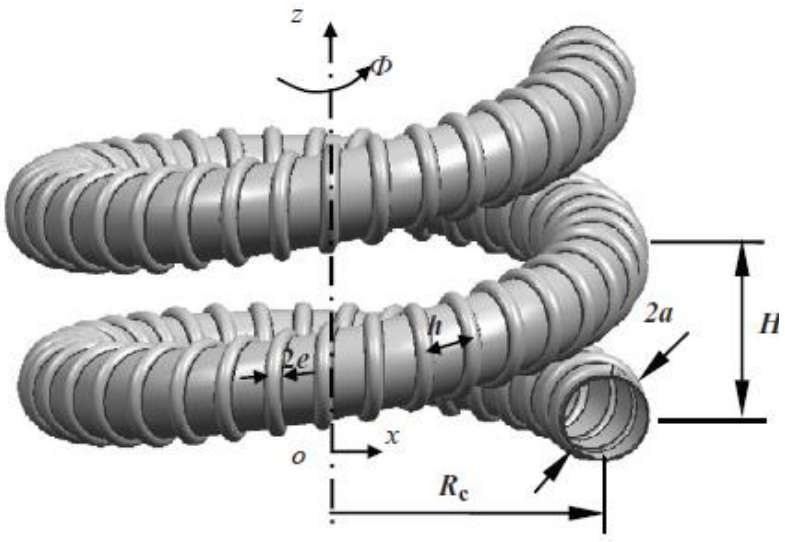

Рис. 12. Фізична модель трубки зі спіральною гофрою
Прийнята модель $k$ - $\varepsilon$ реалізованої турбулентності, а керуючі рівняння вирішені методом контрольного об'єму програмним забезпеченням CFD пакету FLUENT 6.3. Для складності фрізичних моделей геометрія спіральної трубки, яка має спіральну гофру, встановлюється програмним забезпеченням UG. 4.0 та сітка створюється за допомогою використання GAMBIT 2.3 пакету FLUENT, починаючи з його примітивів. З'єднання швидкості тиску здійснюється на основі схеми SIMPLEC. Моментальні, турбулентні та енергетичні рівняння дискретизуються схемою підсвічування другого порядку. Для дискретизації керуючих та енергетичних рівнянь використовується неструктурована неоднорідна сітка. Тривимірна сітчаста система показана на рис. 13.
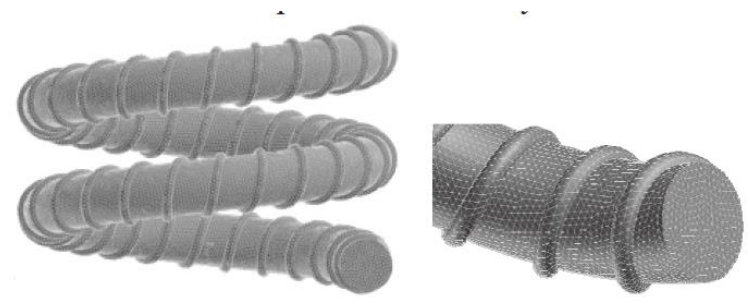

Рис. 13. Обчислювальні сітки

Результати авторів показують, що спіральне гофрування може додатково підвищувати теплообмін гладкої спіральної трубки за рахунок додаткового закрученого руху. Зниження серцевини спірального гофрування може посилити теплообмін в трубці. Перевагою $є$ збільшення теплопередачі на $50-80 \%$, а недоліком $є$ те, що опір потоку на 50-300\% більше, ніж у гладкій гвинтовій трубці.

Гвинтовий рух ідеально стиснутої рідини в трубі. В роботі [19] вирішувалася лінійна задача про рух ідеальної стисливої рідини, близькому до гвинтового руху в нескінченній трубі. В системі координат $\mathrm{Ox}_{1} \mathrm{x}_{2} \mathrm{X}_{3}$, рівномірно обертається 3 кутовою швидкістю $\vec{\omega}_{0}=\omega_{0} \vec{e}_{3}$, рух рідини близький до рівномірного переміщення $з$ постійною швидкістю $\vec{v}_{0}=v_{0} \vec{e}_{3}$ уздовж осі труби.

Для опису малих відхилень від такого гвинтового руху виникає наступна початковокрайова задача:

$$
\begin{gathered}
\partial \vec{u} / \partial t+v_{0}\left(\partial \vec{u} / \partial x_{3}\right)+\nabla p+2 \omega_{0} \vec{u} \times \vec{e}_{3}=\overrightarrow{0} \\
\vec{u}(0, x)=\vec{u}^{0}(x), x \in \tilde{\Omega}:=\Gamma \times(-\infty, \infty) \\
\partial p / \partial t+v_{0}\left(\partial p / \partial x_{3}\right)+\beta^{2} \operatorname{div} \vec{u}=0 \\
p(0, x)=p^{0}(x), x \in \tilde{\Omega} \\
u_{n}=0, x \in S,
\end{gathered}
$$


де $\vec{u}(t, x)$ та $p(t, x), x=\left(x_{1}, x_{2}, x_{3}\right) \in \tilde{\Omega},-$ швидкість частинок та тиск в рідині, $\beta^{2}>0$ та $v_{0}>0-$ коефіцієнт стиснення та швидкість поступального руху рідини, Г та S - поздовжній перетин та бокова поверхня труби.

Залежності (11) - (13) аналогічні залежностям як і в задачі Коши в просторі та мають абстрактний вигляд:

$$
\begin{gathered}
d y / d t+i C y=0 \\
y(0)=y^{0}=\left(\overrightarrow{u^{0}}(x), p^{0}(x)\right)^{\tau} .
\end{gathered}
$$

Турбулентна структура потоку в каналах утворених пучками витих твелів та труб овальної форми. Авторами роботи [20] було розроблено системи рівнянь, які описують турбулентну течею з врахуванням впливу міжканального перемішування теплоносія та ефектів нестаціонарності на поля температур теплоносія та витих твелів (твердої фази) при використанні двухтемпературної моделі течії гомогенізованого середовища. При цьому параметри, які визначають процес течії невеликі, а їх тривалість значно перевищує час розповсюдження звукової хвилі по доважені пучка, для нестаціонарної осесиметричної задачі має вигляд:

$$
\begin{gathered}
\rho_{s} c_{s} \frac{\partial T_{s}}{\partial \tau}=q_{v}-\frac{4 \alpha \varepsilon}{d_{e q}(1-\varepsilon)}\left(T_{s}-T\right)+ \\
+\frac{1}{r} \frac{\partial}{\partial r}\left(r \lambda_{s r} \frac{\partial T_{s}}{\partial r}\right)+\frac{\partial}{\partial x}\left(r \lambda_{s x} \frac{\partial T_{s}}{\partial x}\right), \\
\rho c_{p} \frac{\partial T}{\partial \tau}=\rho u c_{p} \frac{\partial T}{\partial x}=\frac{4 \alpha}{d_{e q}}\left(T_{s}-T\right)+ \\
+\frac{1}{r} \frac{\partial}{\partial \tau}\left(r \lambda_{e f f} \frac{\partial T}{\partial r}\right)+\frac{\partial}{\partial x}\left(\lambda_{e f f} \frac{\partial T}{\partial x}\right) \\
\rho u \frac{\partial u}{\partial x}=-\frac{\partial p}{\partial x}-\varepsilon \frac{\rho u^{2}}{2 d_{e q}}+\frac{1}{r} \frac{\partial}{\partial r}\left(\rho r v_{e f f} \frac{\partial u}{\partial r}\right) \\
G(\tau)=2 \pi \int_{0}^{r k} \varepsilon \rho u r d r \\
p=\rho R T
\end{gathered}
$$

де с - теплоємність, $\rho$ - щільність теплоносія, $d_{e q}$ - еквівалентний діаметр, $G$ - масові витрати теплоносія, $p$ - тиск, $r$ - радіальна координата, $T$ - температура, $u$ - поздовжня швидкість, $x$ - поздовжня координата, $\alpha$ - коефіцієнт тепловіддачі, $\varepsilon$ - пористість пучку по теплоносію, $\lambda$ - теплопровідність, $v$ - кінематична в'язкість, $\lambda$ - щільність, $v$ - час. Індекси: $b$ - середньомасовий, eff - ефрективний, eq - еквівалентний, $p-$ при тиску $P=$ const, $r$ - по вісі $r$, $s$ - тверда фраза, $x$ - по вісі $x$.
Перевагою даної математичної моделі $€$ те, що ця система рівнянь дозволяє розрахувати поля температур при нестаціонарних теплогідравлічних процесах як в моделях пучків витих труб (стержнів) при їх нагріванні електричним струмом, так й в токах високого опору.

Теплообмін при ламінарній течії в кільцевому каналі при підводі маси. Авторами роботи [21] було розглянуто ламінарний потік рідини в кільцевому каналі. При цьому фрізичні властивості рідини $є$ постійними. В'язкісною дисипацією тепла в потоці автори знехтували. Задача має вигляд:

- рівняння нерозривності:

$$
\frac{\partial(\rho u r)}{\partial x}+\frac{\partial(\rho v r)}{\partial r}=0,
$$

де $\rho$ - щільність; $u$ - поздовжня компонента швидкості; $r$ - радіальна координата; $x$ - безрозмірна поздовжня координата; $v$ - радіальна компонента швидкості на зовнішній поверхні каналу;

- рівняння руху:

$$
u \frac{\partial u}{\partial x}+v \frac{\partial u}{\partial r}=-\frac{1}{\rho} \frac{\partial \rho}{\partial x}+\frac{1}{r}\left(r v \frac{\partial u}{\partial r}\right),
$$

- рівняння енергії для потоку:

$$
u \frac{\partial T}{\partial x}+v \frac{\partial T}{\partial r}=\frac{1}{r} \frac{\partial}{\partial r}\left(r a \frac{\partial T}{\partial r}\right)
$$

де $T$ - температура; $a$ - коефіцієнт температуропровідності;

- граничні умови:

$$
\begin{aligned}
& \text { при } r=r_{1}, T=T_{w}, u=v=0, \\
& \text { при } r=r_{2}, \partial T / \partial T_{v}, u=u_{v}, v=0 .
\end{aligned}
$$

Рівняння руху та енергії можливо представити в загальному вигляді:

$$
\frac{\partial \Phi}{\partial x}+(a+b w) \frac{\partial \Phi}{\partial w}=\frac{\partial}{\partial w}\left(c \frac{\partial \Phi}{\partial w}\right) d,
$$

де

$$
\begin{array}{cc}
a=-\frac{\partial \psi_{I} / \partial x}{\psi_{E}-\psi_{I}}, & c=\frac{r^{2} \rho u F_{\phi}}{\left(\psi_{E}-\psi_{I}\right)^{\prime}} \\
d=\frac{S_{\phi}}{\rho u}, & w=\frac{\psi-\psi_{I}}{\psi_{E}-\psi_{I}}
\end{array}
$$

де $\Phi$ - повздовжня швидкість та температура, $F_{\phi}$ - відповідний коефіцієнт дифузії, $S_{\phi}$ - об'ємне джерело, $\psi_{I}, \psi_{E}$ - функція струму на внутрішній та зовнішній стінках кільцевого каналу відповідно.

Теплообмін та гідродинаміка в каналах 3 загвинчувальними пристроями. Авторами роботи [22] були визначено, що поля локальних швидкостей, тисків та температур при течії в каналі будь якої складної форми описується диферен- 
ціальними рівняннями: динаміки суцільного середовища в напруженнях, рівняння нерозривності та рівняння енергії, які виражають відповідно закони збереження імпульсу, маси та енергії:

$$
\begin{gathered}
\frac{\partial \rho u}{\partial T}+(u \nabla) \rho u=F+\operatorname{Div} \vec{\sigma}, \\
\frac{\partial \rho}{\partial T}+\operatorname{div}(\rho u)=0, \\
\rho c_{p} \frac{\partial t}{\partial T}+\rho c_{p} u g r a d t=-\operatorname{div} q+q_{v} .
\end{gathered}
$$

де $u$ - вектор миттєвого значення швидкості, $t-$ миттєве значення температури, $\rho, c_{p}$ - щільність та ізобарна питома теплоємність рідини (теплоносія), q - щільність повного теплового потоку, яка обумовлена різними механізмами переносу енергії, $q_{v}$ - об'ємна щільність внутрішніх джерел тепла, $T$ - час.

Кінцеве значення рівняння нерозривності (25) для циліндричної системи координат $r, \varphi, z$ буде мати вид:

$$
\frac{\partial \rho}{\partial T}+\frac{1}{r} \frac{\partial\left(\rho r u_{r}\right)}{\partial r}+\frac{1}{r} \frac{\partial\left(\rho u_{\varphi}\right)}{\partial \varphi}+\frac{\partial\left(\rho u_{z}\right)}{\partial z}=0
$$

а рівняння енергії (26) у циліндричних координатах буде мати вигляд:

$$
\begin{gathered}
\rho c_{p}\left(\frac{\partial t}{\partial T}+\frac{\partial\left(r u_{r} t\right)}{r \partial r}+\frac{\partial\left(u_{\varphi} t\right)}{r \partial \varphi}+\frac{\partial\left(u_{z} t\right)}{\partial z}\right)= \\
=-\left(\frac{1}{r} \frac{\partial\left(r q_{r}\right)}{\partial r}+\frac{\partial q_{\varphi}}{r \partial \varphi}+\frac{\partial q_{z}}{\partial z}\right)+q_{v}
\end{gathered}
$$

де $q_{i}(i=r, \varphi, z)$ - проекція вектору щільності теплового потоку $q$, яке відповідає направленням координатних осей.

Гідродинаміка та теплообмін в трубах 3 локальними завихрювачами. В якості характерної геометрії каналів з завихрювачами, які утворюють закрутку потоку поблизу теплопередаючої поверхні при помірному збільшенні потужності на прокачування, розглядається геометрія круглих каналів з локальними періодично розповсюдженими спіральними завихрювачами, які виконані у вигляді багатозахідного спірального оребрення внутрішньої поверхні труби, як зображено на рис. 14. Закручена течія при періодичному розповсюдженні завихрювачів, не повністю перекриваючих прохідний перетин каналів, є нестійким та характеризується змінними по довжині каналу полями швидкості та тиску. В зоні розповсюдження завихрювачів $l_{1}$ закрутка буде наростати, досягаючи максимального значення на виході з цієї зони, а в зоні відсутності завихрювачів $l_{2}-$ зменшується до певного рівня, поки потік не досягне наступної ділянки з закручувальними елементами [22-23].

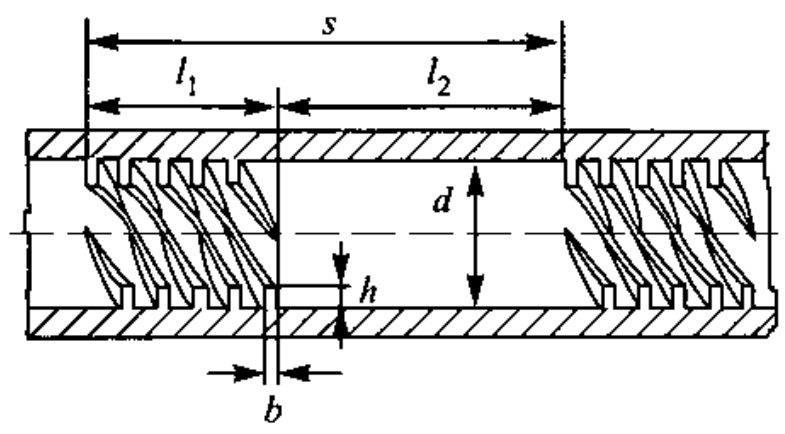

Рис. 14. Схема каналу з періодично розташованими локальними закручувачами. S - крок розташування ділянок з закручувальними елементами, / 1 - область розташування закручувачів (зона генерації закрутки), l2 - довжина ділянки на кроці S, де закручувачі відсутні (зона затухання закрутки)

Кінцевий вид інтегрального рівняння для окружної компоненти вихору:

$$
\begin{gathered}
\frac{\partial}{\partial z} \int_{0}^{R} \frac{\rho\left(u_{r}^{2}-u_{\varphi}^{2}\right)}{r} d r+\frac{\partial^{2}}{\partial z^{2}} \int_{0}^{R} \rho u_{z} u_{r} d r- \\
-\left.\rho u_{z} \frac{\partial u_{z}}{\partial z}\right|_{0} ^{R}=\frac{\partial^{2}}{\partial z^{2}} \int_{0}^{R_{0}} \tau_{r z} d r- \\
-\left.\frac{\partial\left(r \tau_{r z}\right)}{r \partial r}\right|_{0} ^{R_{0}}-\left.\frac{\partial \tau_{r z}}{\partial z}\right|_{0} ^{R_{0}}+ \\
+\frac{\partial}{\partial z} \int_{R_{0}-h}^{R_{0}} f_{\tau} d r-\left.f_{z}\right|_{R_{0}-h} ^{R_{0}}
\end{gathered}
$$

де $\tau_{i j} \quad(i, j=r, \varphi, z \quad$ - компоненти тензора ефективних поверхонь напружень; $R_{0}$ внутрішній радіус каналу; $u_{r}, u_{\varphi}$ та $u_{z}-$ відповідно радіальна, кутова та осьова компонента швидкості; $f_{\tau}$ та $f_{z}$ - опори; $\rho$ щільність; $R$ - довільний; $h$ - висота оребрення.

Канал, який є зазором, утвореним стінкою трубки та паралельними пластинками-капілярами. В роботі авторів [24] був визначений загальний перепад тиску. У статистичному стані, коли відсутній теплообмін, кривизна менісків для всіх капілярів однакова. Радіус кривизни меніску $r$ за умовою, якщо меніск торкається верхнього кінця капіляру, визначається кількістю заповненої рідини, відстань між пластинами $\delta$ та кутом змащування $\theta$ (рис. 15).

При русі рідини тиск у напрямку потоку падає та відповідно збільшується кривизна менісків у напрямку потоку. При цьому перепад тиску між сусідніми капілярами визначається різницею капілярних тисків: 


$$
\Delta p=\frac{\sigma}{r_{i+1}}-\frac{\sigma}{r_{i}}
$$

де $\sigma$ - коефіцієнт поверхневого натягу.

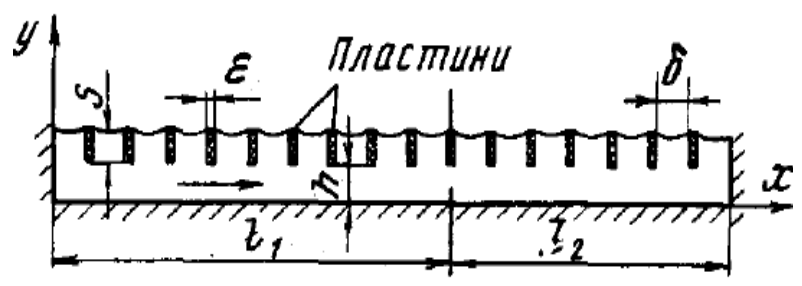

a

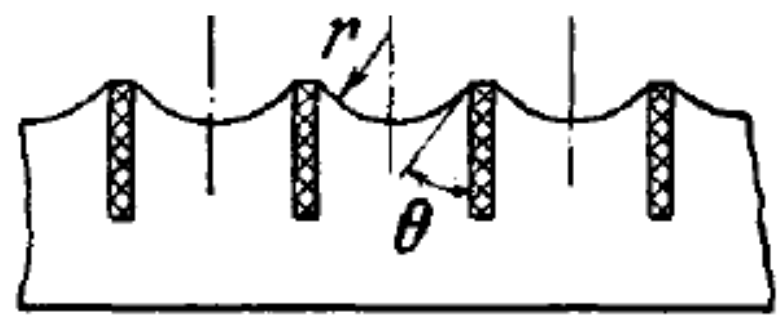

6

Рис. 15. Схема з плоскими капілярами

Тоді загальний перепад тиску має вид:

$$
\Delta p=\frac{\sigma}{r_{n}}-\frac{\sigma}{r_{1}}
$$

Цей перепад тиску повинен бути рівним перепаду тиску, виникаючому при течії рідини з врахуванням дій сил в'язкості:

$$
\Delta p_{1}=\Delta p_{2}+\Delta p_{3}+\Delta p_{4}+\Delta p 5,
$$

де $\Delta p_{2}$ та $\Delta p_{3}$ - перепади в зазорі відповідно на ділянці конденсації та випаровування;

$\Delta p_{4}$ та $\Delta p_{5}$ - перепади тиску в капілярах відповідно на ділянках конденсації та випаровування.

Система рівнянь, які описують течію, при вибраній системі координат (рис. 15):

$$
\begin{gathered}
u \frac{\partial u}{\partial x}+\frac{v}{h} \frac{\partial u}{\partial \eta}=-\frac{1}{p} \frac{\partial p}{\partial x}+ \\
+v\left(\frac{\partial^{2} u}{\partial x^{2}}+\frac{1}{h^{2}} \frac{\partial^{2} u}{\partial \eta^{2}}\right) \\
u \frac{\partial u}{\partial x}+\frac{v}{h} \frac{\partial u}{\partial \eta}= \\
=-\frac{1}{h p} \frac{\partial p}{\partial \eta}+v\left(\frac{\partial^{2} v}{\partial x^{2}}+\frac{1}{h^{2}} \frac{\partial^{2} v}{\partial \eta^{2}}\right), \\
\frac{\partial u}{\partial x}+\frac{1}{h} \frac{\partial v}{\partial \eta}=0,
\end{gathered}
$$

де $\eta$ - безмірна координата $\left(\eta=\frac{y}{h}\right)$, (33), (34) рівняння руху, (35) - рівняння нерозривності.
Теплопередача ламінарного потоку в крученому квадратному каналі для постійного граничного стану теплового потоку через стінку. За допомогою програмного забезпечення FLUENT (версії 6.2.16) автори роботи [25] мали можливість забезпечувати вирішення задачі потоку рідини та теплопередачі за допомогою концепції періодичного потоку. Геометрія моделі складається з модулів довжини L, з постійним падінням тиску вздовж напрямку потоку на кожному повторюваному модулі. Рішення задачі можливо отримати у FLUENT шляхом моделювання одного модуля. Для одержання рішення була використана концепція одичного потоку. Це дозволило використати масштабовану модель та скоротило час обчислення. Під час аналізу автори використали тривимірні моделі з сітчастими елементами шестигранника. Сили тертя, обумовлені наявністю гравітації нехтують. Отримано рішення для стаціонарного, нестисненого, гідродинамічно та термічно розвиненого потоку. На рис. 16 показана сітчаста модель з 80000 елементами. Температура стінки $\left(T_{w}\right)$, об'ємні температури $\left(T_{b}\right)$, тепловий потік $\left(q^{\prime \prime}\right)$ та напруження зсуву $\left(\tau_{\omega}\right)$ отримують на різних місцях розташування по довжині протоки.

Коефіцієнт тертя можна отримати від напруги зсуву стінки як:

$$
f=\tau_{\omega}\left(\frac{\rho V_{m}^{2}}{2}\right)^{-1}
$$

де $\tau_{\omega}$ - напруження зсуву; $\rho$ - щільність рідини; $V_{m}$ - швидкість потоку в крученій трубці.

Коефіцієнт тепловіддачі $(h)$ та число Нуссельта $(N u)$ були обчислені в кожному місці вздовж довжини трубки і навколо стінки:

$$
h=\frac{q "}{\left(T_{w}-T_{b}\right)}
$$

$q$ " - стіновий тепловий потік; $T_{w}$ - температура стінки; $T_{b}$ - об'ємні температури.

$$
N u=\frac{h d}{k} \text {. }
$$

$h$ - коефіцієнт тепловіддачі; $d$ - гідравлічний діаметр каналу; $k$ - теплопровідність рідини.

Для крученого каналу модифікована фоома параметра закрутки для скрученої стрічки визначається за формулою:

$$
S_{w}=\frac{R e}{\sqrt{H}_{r}}
$$

$S_{w}$ - параметр вихору;

$H_{r}$ - коефіцієнт повороту.

Параметр вихору є функцією співвідношення числа і площі Рейнольдса і обернено 
пропорційний до квадратного кореня закрутки та визначається як:

$$
A_{r}=\frac{A_{s t}}{A_{t w}} .
$$

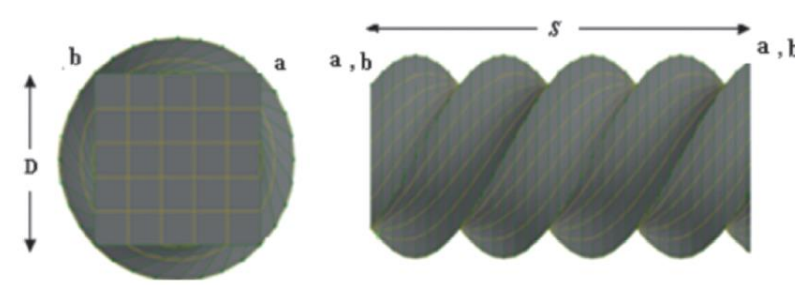

a

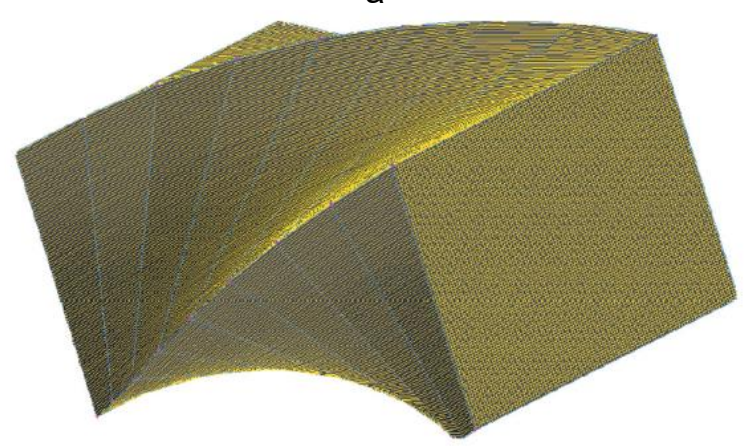

6

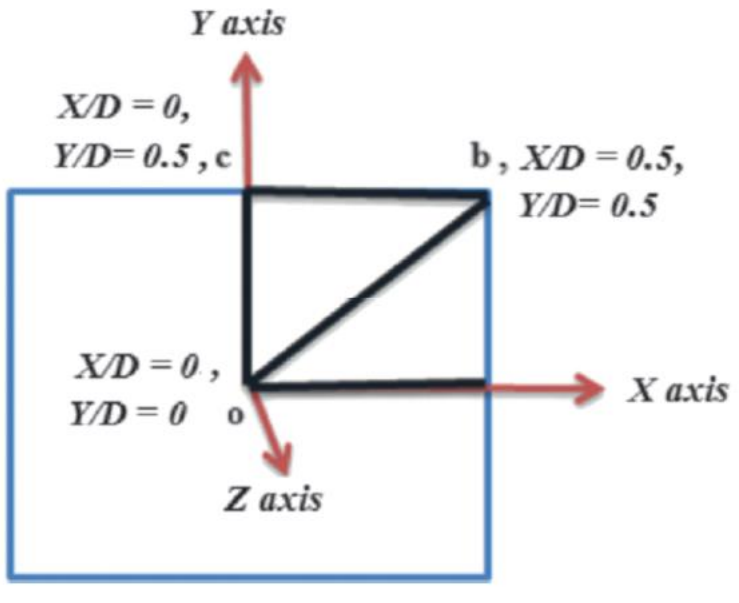

B

Рис. 16. Скручений квадратний канал: а - профіль скрученої труби;

б - обчислювальна сітка; в - поперечний переріз квадратного каналу

Фізично це відношення площі теплопередачі крученої трубки до її розкрученого аналога, що має однакову площу перерізу потоку і однакова довжина потоку. Пряма передача тепла квадратної труби визначається за фрормулою:

$$
A_{s t}=4 S d_{h},
$$

$S$ - поріг крученої трубки.

Площа передачі тепла для крученого квадратного каналу визначається залежністю:

$$
\begin{gathered}
A_{t w}=4 \pi d_{h}^{2}\left[0,5\left(1+\frac{H^{2}}{\pi^{2}}\right)+\right. \\
+\frac{H^{2}}{2 \pi^{2}} \ln \left\{\frac{\pi}{H}+\left(1+\frac{\pi^{2}}{H^{2}}\right)^{\frac{1}{2}}\right\}
\end{gathered}
$$

Теплопередачі в U-подібній трубчастій трубці зі стрічковими вкладишами. В роботі [26] представлено математична модель, яка передбачає неізотермічний ламінарний потік. Модель включає рівняння безперервності та рівняння Ер-Стокса:

$$
\begin{gathered}
\frac{\partial \rho}{\partial t}+\nabla(\rho u)=0 \\
\rho \frac{\partial u}{\partial t}+\rho(u \cdot \nabla) u=\nabla \cdot[-P I+\lambda]+F
\end{gathered}
$$

Проблема передачі тепла вирішується через властивості рідину. При цьому керуються наступним рівнянням:

$$
\begin{gathered}
\rho C_{p}\left(\frac{\partial T}{\partial t}+(u \cdot \nabla) T\right)=(\nabla \cdot q)+\tau: S- \\
-\left.\frac{T}{\rho} \frac{\partial \rho}{\partial t}\right|_{p}\left[\frac{\partial \rho}{\partial t}+(u \cdot \nabla) p\right]+Q
\end{gathered}
$$

$\tau: S$ - в'язке нагрівання рідини;

$$
\begin{gathered}
S=\frac{1}{2}(\nabla u+(\nabla u) T) \\
\rho C_{p} \frac{\partial T}{\partial t}+\rho C_{p}(u \cdot \nabla) T=-\nabla \cdot(K \nabla T)+Q
\end{gathered}
$$

$Q$ - джерело тепла, відмінне від в'язкого нагрівання; $K$ - конвективний тепловий потік;

Якщо швидкість дорівнює нулю, то рівняння має вигляд:

$$
\rho C_{p} \frac{\partial T}{\partial t}-\nabla \cdot(K \nabla T)=Q
$$

Конвективний коефіцієнт тепловіддачі отримують вид:

$$
h=\frac{Q}{T_{w}-T_{b}}
$$

де $T_{w}$ та $T_{b}$ температура стінки і об'ємна температура, де $T_{b}=\frac{T_{\text {out }}+T_{\text {in }}}{2}$.

Кількість Нуссельта обчислюється за формулою:

$$
N u=\frac{h D}{k}
$$

$D$ - діаметр трубки. 
Теплові показники розраховуються як

$$
\eta=\frac{h_{s}}{h_{p}}
$$

де $\eta$ - теплові показники, а $h_{s}, h_{p} i h_{f}$ - тепловіддача на коротку довжину, звичайна трубка та повна довжина вставляють коефіцієнт тепловіддачі відповідно.

\section{Висновки}

1. Проведений огляд літературних джерел дозволили виконати комплексну оцінку математичних моделей гідродинаміки та теплообміну в трубах з інтенсифрікаторами теплообміну. Встановлено, що застосування труб з однозахідною або багатозахідною накаткою $є$ перспективним методом інтенсифрікації теплообміну.

2. При ламінарних режимах течії визначальним механізмом перенесення тепла $є$ теплопровідність (поперек потоку, по нормалі до стінки), тому інтенсивність тепловіддачі відносно мала, отже для підвищення теплопередачі треба використовувати труби з гвинтовою поверхнею теплообміну (труби з однозахідною та багатозахідною спіральною накаткою), в яких відбувається ламінарний закручений рух рідини.

3. На відміну від турбулентної течії, в ламінарному (перехідному) потоці термічний опір в каналі більш рівномірно розподілений по всьому його поперечному перерізі, тому для інтенсифікації тепловіддачі необхідний вплив, що збурює на велику зону пристінної течії.

4. Використання труб з спіральною накаткою в енергетичних палях з інтегрованими теплообмінниками дозволить знизити масогабаритні характеристики не тільки теплообмінника, а й самої палі.

\section{Література}

1. Лобанов И. Е. Теоретические и экспериментальные исследования интенсифицированного теплообмена при турбулентном течении в трубах с применением ленточных закручивателей потока / И.Е. Лобанов, А.В. Дедов // Альманах современной науки и образования. Тамбов: Грамота, 2010. № 10 (41). - C. 55-70. - URL: www.gramota.net/materials/1/2010/10/20.html. (дата обращения: 20.08.2019).

2. Кишкин А. А. Интенсификация теплообмена / А.А. Кишкин, М.В. Краев, А.А. Зуев // Вестник Сибирского государственного аэрокосмического университета им. Академика М.Ф. Решетнева. Красноярск, 2005. № 3. - С. 130-134. URL: https://cyberleninka.ru/article/v/intensifikatsiyateploobmena. (дата обращения: 20.08.2019).

3. Лобанов И. Е. Математическое моделирование теплообмена при искусственной турбулизации потока в плоских каналах с турбулизаторами на обеих сторонах. Альманах современной науки и образования. Тамбов: Грамота, 2010. № 7 (38). - C. 62-71. - URL: http://www.gramota.net/ materials/1/2010/7/18.html. (дата обращения: 20.08.2019).

4. Дрейцер Г. А., Лобанов И. Е. Исследование предельной интенсификации теплообмена в трубах за счет искусственной турбулизации потока // Теплофизика высоких температур. 2002. Т. 40. № 6. С. 958-963.

5. Дрейцер Г.А., Лобанов И.Е. Математическое моделирование предельного интенсифи цированного теплообмена при применении ленточных закручивателей в трубах с турбулизаторами // Тезисы докладов Второй российской конференции "Тепломассообмен и гидродинамика в закрученных потоках". М.: Издво МЭИ, 2005. С. 193-194.

6. Дрейцер Г.А., Лобанов И.Е. Моделирование предельной интенсификации теплообмена в круглых трубах и кольцевых каналах за счет искусственной турбулизации потока для различных теплоносителей с постоянными и переменными теплофизическими свойствами // Газотурбинные и комбинированные установки и двигатели: сб. тезисов докладов XII Всероссийской межвузовской научно-технической конфреренции. М., 2004. С. 99-100.

7. Дрейцер Г. А., Лобанов И. Е. Моделирование предельной интенсификации теплообмена в трубах за счет искусственной турбулизации потока для различных теплоносителей с постоянными и переменными теплофизическими свойствами // Тезисы докладов и сообщений V Минского международного форума по тепломассообмену. Минск, 2004. Т. 1. С. 67-69.

8. Дрейцер Г.А., Лобанов И.Е. Моделирование предельной интенсификации теплообмена в трубах за счет искусственной турбулизации потока для различных теплоносителей с постоянными и переменными теплофизическими свойствами // Труды V Минского международного форума по тепломассообмену. Минск, 2004. Т. 1. № 27. С. 1-9.

9. Дрейцер Г. А., Лобанов И. Е. Предельная интенсификация теплообмена в трубах за счет искусственной турбулизации потока // Инженернофризический журнал. 2003. Т. 76. № 1. С. 46-51.

10. Лобанов И. Е. Моделирование предельного теплообмена посредством турбулизации потока для кольцевых каналов // Проблемы тепломассообмена и гидродинамики в энергомашиностроении: труды IV школы-семинара молодых ученых и специалистов под руководством акад. РАН В. Е. Алемасова. Казань: КГУ, 2004. С. 134-142.

11. Мигай В. К. Интенсификация конвективного теплообмена в трубах и каналах тепло- 
обменного оборудования: дисс. ... д-ра техн. наук. Л., 1973. Т. 1. 327 с.

12. Мигай В.К. Интенсификация конвективного теплообмена в трубах и каналах теплообменного оборудования: приложение к дисс. ... д-ра техн. наук. Л., 1973. Т. 2. 85 с.

13. Новожилов И.Ф., Мигай В.К. Интенсификация конвективного теплообмена внутри труб путем применения искусственной шероховатости // Теплоэнергетика. 1964. С. 57-63.

14. Петухов Б.С., Генин Л.Г., Ковалев С.А. Теплообмен в ядерных энергетических установках. М.: Энергоатомиздат, 1986. 470 с.

15. Ахметов Ю. М. Возможный механизм течения вихревых закрученных потоков / Ю. М. Ахметов, Э. И.Зангиров, А. В. Свистунов // Тр. МФТИ. - 2014. - Т. 6, № 2. - С. 99-104. - URL: https://cyberleninka.ru/article/n/vozmozhnyymehanizm-techeniya-vihrevyh-zakruchennyhpotokov. (дата обращения: 20.08.2019).

16. Ахметов А. Ю. Исследование влияния тормозного устройства на структуру потока и параметры изотермического вихревого регулятора давления / Вестник УГАТУ. Уфа: УГАТУ, 2011. Т. 15, № 4(44). С. 149-153.

17. Багоутдинова А. Г. Визуализация процессов гидродинамики и теплообмена в трубах с винтовой поверхностью теплообмена / А. Г. Багоутдинова, Я. Д. Золотоносов // Известия государственного архитектурно-строительного университета. Казань, 2014. - № 2(28). - С. 108-115. - UTL: https://cyberleninka.ru/article/n/vizualizatsiyaprotsessov-gidrodinamiki-i-teploobmena-v-trubah-svintovoy-poverhnostyu-teploobmena. (дата обращения: 20.08.2019).

18. Li Y. Fluid flow and heat transfer characteristics in helical tubes cooperating with spiral corrugation / Y. Li, J. Wu, H. Wang, L. Kou, X. Tian // Energy Procedia, 2012. - № 17. - pp. 791-800. URL: http://dx.doi.org/10.1016/j.egypro.2012.02.172. (date of appeal: 20.08.2019).

19. Аширов А. К проблеме винтового движения идельной сжимаемой жидкости в трубе // A. Аширов, Н. Д. Копачевский, 3. 3. Ситшаева / Book of Abstracts of the XXIII Crimean Autumn Math. School-Sympos. - Симферополь: изд-во КНЦ HAHУ, 2012. - C. 61-63. - URL: http://nikolay-dkopachevsky.com/files/203.pdf. (дата обращения: 20.08.2019).

20. Дзюбенко Б.В. Тепломассообмен в каналах с закруткой потока / Б.В. Дзюбенко, А.С. Мякочин, Н.У. Щербакова // Современная наука: исследования, идеи, результаты, технологии. Днепропетровск: НПВК "Триакон". - 2011. - Вып. 2(7). - C. 17 - 22. - URL: http://modern.science. triacon.org/ru/issues/2011/files/2011_2(7)_3.htm. (дата обращения 20.08.2019).
21. Грошев А.И. Теплообмен при ламинарном течении в кольцевом канале при подводе массы / А.И. Грошев, Л.Т. Зубков, В.В. Худаско, В.П. Югов // ФЭИ-1798, Обнинск: ФЭИ, 1986 г. - 11 с.

22. Митрофранова О. В. Гидродинамика и теплообмен закрученных потоков в каналах ядерно-энергетических участков. - М.: ФИЗМАТЛИТ, 2010. -288 c.

23. Митрофанова О.В. Гидродинамика и теплообмен закрученных потоков в каналах с завихрителями (Аналитический обзор) // Теплофизика высоких температур, 2003, Т. 41, № 4, С. 587-633.

24. Потапов Ю.Ф. Исследование гидродинамики течения жидкости в канале тепловой трубки // Учебные записки ЦАГИ, 1970, Т.1, № 3, С. 126-131.

25. Bhandouriya R. Laminar flow heat transfer studies in a twisted square duct for constant wall heat flux boundary condition / R. Bhandouriya, A. Agrawal, S.V. Prabhu // International Journal of Thermal Sciences, № 94, 2015, pp. 96-109. - URL: https://doi.org/10.1016/j.ijthermalsci.2015.02.019. (date of appeal: 20.08.2019).

26. Md. Moniruzzaman Bhuyan, Ujjwal K. Deb, M. Shahriar, Simul Acherjee Simulation of Heat Transfer in a Tubular Pipe Using Different Twisted Tape Inserts // Open Journal of Fluid Dynamics, 2017, № 7, pp. 397-409. - URL: http://www.scirp. org/journal/ojfd. (date of appeal: 20.08.2019).

\section{References}

1. Lobanov, I. and Dedov, A. (2010). Teoreticheskie i jeksperimental'nye issledovanija intensificirovannogo teploobmena pri turbulentnom techenii $v$ trubah s primeneniem lentochnyh zakruchivatelej potoka. Al'manah sovremennoj nauki i obrazovanija, [online] 10 (41)(1993-5552), pp.55-70. Available at: http://www.gramota.net/materials/1/2010/10/20.html [Accessed 20 Aug. 2019].

2. Kishkin, A., Kraev, M. and Zuev, A. (2005). Intensifikacija teploobmena. Vestnik Sibirskogo gosudarstvennogo ajerokosmicheskogo universiteta im. Akademika M.F. Reshetneva. Krasnojarsk, [online] 3, pp.130-134. Available at: https://cyberleninka.ru/article/v/intensifikatsiya-teploobmena [Accessed 20 Aug. 2019].

3. Lobanov, I. (2010). Matematicheskoe modelirovanie teploobmena pri iskusstvennoj turbulizacii potoka $v$ ploskih kanalah $s$ turbulizatorami na obeih storonah. Al'manah sovremennoj nauki i obrazovanija, [online] 7 (38)(1993-5552), pp.62-71. Available at: http://www.gramota.net/materials/1/2010/7/18.html [Accessed 20 Aug. 2019].

4. Drejcer, G. (2002). Issledovanie predel'noj intensifikacii teploobmena $v$ trubah za schet 
iskusstvennoj turbulizacii potoka. Teplofizika vysokih temperatur, 40(6), pp.958-963.

5. Drejcer, G. and Lobanov, I. (2005). Matematicheskoe modelirovanie predel'nogo intensificirovannogo teploobmena pri primenenii lentochnyh zakruchivatelej $\mathrm{v}$ trubah $\mathrm{s}$ turbulizatorami. Tezisy dokladov Vtoroj rossijskoj konferencii "Teplomassoobmen i gidrodinamika $v$ zakruchennyh potokah", pp.193-194.

6. Drejcer, G. and Lobanov, I. (2004). Modelirovanie predel'noj intensifikacii teploobmena $v$ kruglyh trubah i kol'cevyh kanalah za schet iskusstvennoj turbulizacii potoka dlja razlichnyh teplonositelej s postojannymi i peremennymi teplofizicheskimi svojstvami. Gazoturbinnye i kombinirovannye ustanovki i dvigateli. Sb. tezisov dokladov XII Vserossijskoj mezhvuzovskoj nauchnotehnicheskoj konferencii, pp.99-100.

7. Drejcer, G. and Lobanov, I. (2020). Modelirovanie predel'noj intensifikacii teploobmena $\mathrm{v}$ trubah za schet iskusstvennoj turbulizacii potoka dlja razlichnyh teplonositelej $\mathrm{s}$ postojannymi i peremennymi teplofizicheskimi svojstvami. Tezisy dokladov i soobshhenij $V$ Minskogo mezhdunarodnogo foruma po teplomassoobmenu, 1, pp.67-69.

8. Drejcer, G. and Lobanov, I. (2004). Modelirovanie predel'noj intensifikacii teploobmena $v$ trubah za schet iskusstvennoj turbulizacii potoka dlja razlichnyh teplonositelej $s$ postojannymi i peremennymi teplofizicheskimi svojstvami. Trudy V Minskogo mezhdunarodnogo foruma po teplomassoobmenu, 1 (27), pp.1-9.

9. Drejcer, G. and Lobanov, I. (2003). Predel'naja intensifikacija teploobmena $v$ trubah za schet iskusstvennoj turbulizacii potoka. Inzhenernofizicheskij zhurnal, 76 (1), pp.46-51.

10. Lobanov, I. (2004). Modelirovanie predel'nogo teploobmena posredstvom turbulizacii potoka dlja kol'cevyh kanalov. Problemy teplomassoobmena i gidrodinamiki $v$ jenergomashinostroenii: trudy IV shkoly-seminara molodyh uchenyh i specialistov pod rukovodstvom akad. RAN V.E. Alemasova, pp.134-142.

11. Migaj, V. (1973). Intensifikacija konvektivnogo teploobmena $v$ trubah $i$ kanalah teploobmennogo oborudovanija. 1st ed. L.: diss. ... d-ra tehn. nauk., p.327.

12. Migaj, V. (1973). Intensifikacija konvektivnogo teploobmena $\mathrm{v}$ trubah i kanalah teploobmennogo oborudovanija. 2st ed. L.: diss. ... d-ra tehn. nauk., p.85.

13. Novozhilov, I. and Migaj, V. (1964). Intensifikacija konvektivnogo teploobmena vnutri trub putem primenenija iskusstvennoj sherohovatosti. Teplojenergetika, pp.57-63.
14. Petuhov, B., Genin, L. and Kovalev, S. (1986). Teploobmen $v$ jadernyh jenergeticheskih ustanovkah. M.: Jenergoatomizdat, p.470.

15. Ahmetov, J., Zangirov, J. and Svistunov, A. (2014). Vozmozhnyj mehanizm techenija vihrevyh zakruchennyh potokov. Tr. MFTI, [online] 6 (2), pp.99-104. Available at: https://cyberleninka.ru/article/n/vozmozhnyy-mehanizm-techeniya-vihrevyh -zakruchennyh-potokov [Accessed 20 Aug. 2019].

16. Ahmetov, A. (2011). Issledovanie vlijanija tormoznogo ustrojstva na strukturu potoka i parametry izotermicheskogo vihrevogo reguljatora davlenija. Vestnik UGATU, 4(44), pp.149-153.

17. Bagoutdinova, A. and Zolotonosov, J. (2014). Vizualizacija processov gidrodinamiki i teploobmena $v$ trubah $s$ vintovoj poverhnost'ju teploobmena. Izvestija gosudarstvennogo arhitekturno-stroitel'nogo universiteta, [online] 2(28), pp.108-115. Available at: http://cyberleninka.ru/article/n/vizualizatsiya-protsessov-gidrodinamiki-iteploobmena-v-trubah-s-vintovoy-poverhnostyuteploobmena [Accessed 20 Aug. 2019].

18. Li, Y., Wu, J., Wang, H., Kou, L. and Tian, X. (2012). Fluid Flow and Heat Transfer Characteristics in Helical Tubes Cooperating with Spiral Corrugation. Energy Procedia, 17, pp.791-800.

19. Ashirov, A., Kopachevskij, N. and Sitshaeva, Z. (2012). K probleme vintovogo dvizhenija idel'noj szhimaemoj zhidkosti $v$ trube. Book of Abstracts of the XXIII Crimean Autumn Math. School-Sympos, [online] pp.61-63. Available at: URL: http://nikolay-dkopachevsky.com/files/203.pdf [Accessed 20 Aug. 2019].

20. Dzjubenko, B., Mjakochin, A. and Shherbakova, N. (2011). Teplomassoobmen $v$ kanalah $\mathrm{s}$ zakrutkoj potoka. Sovremennaja nauka: issledovanija, idei, rezul'taty, tehnologii, [online] 2(7), pp.17-22. Available at: http://modern. science.triacon.org/ru/issues/2011/files/2011_2(7)_ 3.htm [Accessed 20 Aug. 2019].

21. Groshev, A., Zubkov, L., Hudasko, V. and Jugov, V. (1986). Teploobmen pri laminarnom techenii $v$ kol'cevom kanale pri podvode massy. Obninsk: FJel-1798, p.288.

22. Mitrofanova, O. (2010). Gidrodinamika i teploobmen zakruchennyh potokov $\mathrm{v}$ kanalah jaderno-jenergeticheskih uchastkov. M.: FIZMATLIT, p.288.

23. Mitrofanova, O. (2003). Gidrodinamika i teploobmen zakruchennyh potokov $v$ kanalah $s$ zavihriteljami (Analiticheskij obzor). Teplofizika vysokih temperatur, 41(4), pp.587-633.

24. Potapov, J. (1970). Issledovanie gidrodinamiki techenija zhidkosti v kanale teplovoj trubki. Uchebnye zapiski CAGI, 1(3), pp.126-131. 
25. Bhandouriya, R., Agrawal, A. and Prabhu, S. (2015). Laminar flow heat transfer studies in a twisted square duct for constant wall heat flux boundary condition. International Journal of Thermal Sciences, [online] 94, pp.96-109. Available at: https://doi.org/10.1016/j.ijthermalsci.2015.02.019
[Accessed 20 Aug. 2019].

26. Bhuyan, M., Deb, U., Shahriar, M. and Acherjee, S. (2017). Simulation of Heat Transfer in a Tubular Pipe Using Different Twisted Tape Inserts. Open Journal of Fluid Dynamics, 07(03), pp.397-409.

\title{
Аннотация
}

\section{Анализ теоретических исследований интенсифицированного теплообмена в трубах}

\author{
В.И. Мельник, Б.Н. Цимбал
}

В работе на основе анализа математических моделей обоснованно недостатки и преимущества различных конструкций теплообменников с завихрителями и их влияние на гидродинамику и теплообмен закрученных потоков. Большинство теплообменников с завихрителями имеют сложную фрорму. Увеличение теплообмена при применении винтовых закручивателей потока происходит благодаря интенсификации теплообмена между ядром потока и пограничным слоем. Происходит это при турбулизации закрученного потока под действием центробежных сил. В таком случае эфрфективная скорость выше, чем при обычной турбулентности потока. Процесс протекает более интенсивно при низких числах Рейнольдса.

При ламинарных режимах течения определяющим механизмом переноса тепла является теплопроводность поперек потока, по нормали к стенке. В таком случае интенсивность теплоотдачи относительно мала. Для повышения теплопередачи надо использовать трубы с винтовой поверхностью теплообмена (однозаходной и многозаходной спиральной накаткой), в которых происходит ламинарное закрученное движение жидкости. В отличие от турбулентного течения, В ламинарном потоке термическое сопротивление в канале более равномерно распределено по всему его поперечному сечению, поэтому для интенсификации теплоотдачи необходимо воздействие, которое будоражит поток в пределах зоны пристенного течения.

Наиболее перспективными являются теплообменники из труб с однозаходные или многозаходных спиральной накаткой. В отличие от трубчатых теплообменников без накатки, они имеют большую площадь теплообмена и меньшую материалоемкость. При этом в отличие от ленточных вставок и закручувателей, трубы с накаткой имеют гидравлическое сопротивление пристенного слоя, которое уменьшается быстрее, чем растут потери давления.

Использование труб со спиральной накаткой в энергетических сваях с теплообменниками позволит снизить массогабаритные характеристики не только теплообменника, но и самой сваи. В таком случае интенсификация теплообмена определяется гидродинамикой потока в вязком пристеночном слое, то есть нарушением упорядоченности течения жидкости за счет его закручивания.

Проведенный анализ известных математических моделей интенсификаторов теплообмена позволяет сформировать требования к перспективным конструкциям теплообменников. В дальнейшем это позволит разработать новую математическую модель гидродинамики и теплообмена в забивной сваи с U-образным теплообменником в которой учтены все приведенные в работе недостатки. Опираясь на исследования гидродинамики и теплообменных процессов нужно провести оптимизацию конструкции теплообменника, а именно, геометрию поперечного сечения труб, фоорму укладки труб в теле сваи, а также глубину, угол и ширину углублений спиральной накатки.

Ключевые слова: свая, теплообменник, накатка, теплота, эффрективность, гидравлические потери, число Нусельта, математическая модель, оптимизация.

\section{Abstract}

\section{Analysis of the theoretical studies of the intensified heat exchange in pipes}

\section{V.I. Melnyk, B.M. Tsymbal}

In the process of work on the basis of the analysis of the mathematical models, the disadvantages and advantages of different constructions of heat exchangers with spirals and their influence on the hydrodynamics and on the heat exchange of the spiral flows, are grounded. Most of the spiral heat exchangers have a complex 
shape. When using the screw twists of the flow, the increase of the heat exchange occurs due to the intensification of the heat exchange between the core of the flow and the boundary layer. This occurs during the turbulence of the swirling flow under the influence of the centrifugal forces. In this case, the effective speed is higher than during a normal flow turbulence. The process is more intensive at low Reynolds numbers.

At laminar flow regimes the determining mechanism of heat transfer is the thermal conductivity across the flow along the normal to the wall. In this case, the heat transfer intensity is relatively low. To increase heat transfer, it is necessary to use some pipes with a helical heat exchange surface (with a single-start and multistart spiral knurling), in which there is a laminar spiral motion of the liquid. In contrast to the turbulent flow, in a laminar flow the thermal resistance in the channel is more evenly distributed over its entire cross section, so for the intensification of the heat transfer, some influence disturbing the flow within the wall zone of the flow, is needed.

The most promising are the heat exchangers made of pipes with a single-start or multistart spiral knurling. Unlike the tubular heat exchangers without any knurling, they have a larger heat exchange area and a lower material consumption. At the same time, in contrast to the tape inserts and twists, the pipes with knurling have a hydraulic resistance of the wall layer, which decreases faster than the pressure loss increases.

The use of the pipes with a spiral knurling in energy piles with heat exchangers will reduce the weight and size characteristics not only of the heat exchanger, but also of the pile itself. In this case, the intensification of heat transfer is determined by the hydrodynamics of the flow in a viscous wall layer, i.e. the violation of the order of the liquid flow due to its twisting.

The carried out analysis of the known mathematical models of heat exchange intensifiers allows to form the requirements for some perspective designs of heat exchangers. In the future this will make it possible to develop a new mathematical model of the hydrodynamics and heat transfer in a pile with an U-shaped heat exchanger, which takes into account all the disadvantages identified in the course of work. Based on the studies of the hydrodynamics and heat exchange processes, it is necessary to optimize the construction of the heat exchanger, namely the geometry of the cross section of the pipes, the shape of the pipe laying in the pile body, as well as the depth, angle and width of the spiral knurling deepening.

Keywords: pile, heat exchanger, knurling, heat, efficiency, hydraulic losses

\section{Бібліографічне посилання/ Bibliography citation: Harvard}

Melnyk, V.I. and Tsymbal, B.M. (2020) Analysis of the theoretical studies of the intensified heat exchange in pipes. Engineering of nature management, (1(15), pp. 13 - 28.

Подано до редакції / Received: 18.02.2020 